\title{
Researches Regarding the Influence of the Bulls Age on the Raw and Processed Semen
}

\author{
Bogdan COCAN*, Gheorghe MURESAN \\ Faculty of Animal Science and Biotechnologies, University of Agricultural Sciences \\ and Veterinary Medicine 3-5 Mănăştur Street, 400372 Cluj-Napoca, Romania \\ *Corresponding author, email: cocan_bogdan@yahoo.com
}

Bulletin UASVM Animal Science and Biotechnologies 72(1) / 2015

Print ISSN 1843-5262; Electronic ISSN 1843-536X

DOI:10.15835/buasvmcn-asb:10540

\begin{abstract}
The researches were made within S.C. Semtest BVN Targu Mures on a sample of 1946 ejaculates collected from eight bulls, with the age between two and nine years, of Fleckvieh breed, collected between the year 2000 and 2006. In this direction, to identify main variation sources and the way this factors act upon sperm production and implicitly on the quality of the semen material, sperm parameters were evaluated by the bulls age. Thus, they were determined the following parameters: the volume of the ejaculate, sperm concentration, sperm mobility in raw semen material, sperm mobility in defrosted semen material, obtained and admited doses. Following the researches it was confirmed that the ejaculates volume rises from $6.07 \mathrm{ml}$ at two years category up to $9.61 \mathrm{ml}$ at six years category, after that decreases; the concentration of raw sperm is higher at young bulls, and regarding the number of obtained and admited doses, the age of the bulls has a signifiant influence, with variations showing an ascendent trend depending on the ageing of the bulls. The results are showing, that depending on the age, the volume of the ejaculate grows, raw sperm mobility and concentration is highier at young age and regarding the obtained and admited doses number, they grow along with the age. Semen production, quantitative and also qualitative, is also influenced by the age of the bulls.
\end{abstract}

Keywords: bulls, semen quality, spermiograms

\section{INTRODUCTION}

Genetic improvement of cattle effectives as a activity with primarily character in the progress strategy of Romanian animal husbandry, is achieved by selection actions, made on the base of official control of performances, guided reproduction mostly by artificial insemination (www.anarz.eu). The reproduction process of animals is a national concern activity, which it has as a main objective the rational usage of genetically ameliorated reproduction material, by applying in animal husbandry the modern biotechnology of directed reproduction. The artificial insemination biotechnology represents the main instrument to increase and diffuse the genetic, by using at reproduction the most valuable, materialized work by obtaining higher productions (Miclea, 2003). Given the fact the special importance of the bulls in the process of breeding and improvement of cattle, it's necessary that they must be always in "breeding condition, respectively to have a good health and maintenance, to be vigorous, with high libido, to produce highly quality semen material (Acatincai, 2004).

\section{MATERIALS AND METHODS}

The researches of the present study were carried in S.C. Semtest BVN Târgu Mureş on a number of eight bulls, with age between two and nine years, analized in the period 20002006, from wich it was obtained a number of 168 ejaculates from two years old bulls, 240 ejaculates from three years age old bulls, 246 ejaculates from four years old age bulls, 364 ejaculates from five years old age, 458 ejaculates from six years age old bulls, 331 ejaculates from seven years old bulls, 
90 ejaculates from eight years old bulls and 49 ejaculates from nine years old bulls.

For achieving the evaluation of the spermograms, our researches were performed inside of the Semtest BVN Targu Mures bulls center, one of the elite Romanian centers for animal husbandry, for many years now, carrying activities from reproductive biotechnology field in order to increase the genetic potential of cattle. In this direction, to identify main variation sources and the way this factors act upon sperm production and implicitly on the quality of the semen material, sperm parameters were evaluated by the bulls age. Thereby, they were determined the following parameters: the volume of the ejaculate, sperm concentration, sperm mobility in raw semen material, sperm mobility in defrosted semen material, obtained and admited doses.

\section{RESULTS AND DISCUSSION}

The results of the researches made on the sperm production, on a sample of 1946 ejaculates (Tab. 1), collected from eight bulls of Fleckvieh breed are presented as:

The ejaculate volume, depending on age, rises from $6.07 \mathrm{ml}$ at 2 years category up to $9.61 \mathrm{ml}$ at 6 years category, after that it decreases gradually reaching at nine years old at a medium volume of $7.85 \mathrm{ml}$.

Sperm mobillity presents easy deferences depending on the age meaning that,mobility is between $76.21-76.36 \%$ at 2-3 years, between 4-6 years mobility is about $73.20-75.23 \%$, then after seven years mobility slightly decreases reaching at the value of $71.02 \%$ at nine years old.

Raw sperm concentration is higher at two year bulls, this one being a average of $1.64 \times 10^{9} / \mathrm{ml}$ after that decreases easely till $1.26 \times 10^{9} / \mathrm{ml}$ at the age of six, after is stabillizing around the value of $1.34 \times 10^{9} / \mathrm{ml}$, then starts decreasing.

Following the researches regarding the influence of the bulls age on proccesed sperm production (Tab. 2), within BVN Târgu Mureș they were observed the follwings:

The bulls age has a decisive influence upon the obtained dossage number, with variations wich shows an ascending trend dependind on the bulls aging. Thus, the obtained doses media rised gradualy from 297 at two years old bulls and up to 529 at seven years old bulls, after that drops at 504 doses at eight years and 378 doses at nine years.

The sperm mobility after freezing is not influenced by the bulls age, obtaining variations wich don't show an ascendent trend or descendent

Tab. 1. The influence of the bulls age over brut spermatic production.

\begin{tabular}{|c|c|c|c|c|c|c|}
\hline $\begin{array}{l}\text { Age of } \\
\text { bulls } \\
\text { (years) }\end{array}$ & $\begin{array}{c}\text { Ejaculated } \\
\text { no }\end{array}$ & Statistics & $\begin{array}{l}\text { Volume } \\
\text { (ml) }\end{array}$ & $\begin{array}{l}\text { Mobility } \\
\text { (\%) }\end{array}$ & $\begin{array}{c}\text { Concentration } \\
\left(\mathrm{x} 10^{9} / \mathrm{ml}\right)\end{array}$ & $\begin{array}{c}\text { Concentration } \\
\text { of ejaculate } \\
\left(\times 10^{9}\right)\end{array}$ \\
\hline \multirow{2}{*}{2} & \multirow{2}{*}{168} & $\mathrm{X}$ & 6.07 & 76.21 & 1.64 & 10.20 \\
\hline & & $\pm S_{x}$ & 0.17 & 0.51 & 0.05 & 0.40 \\
\hline \multirow{2}{*}{3} & \multirow[b]{2}{*}{240} & $X$ & 8.15 & 76.36 & 1.48 & 12.23 \\
\hline & & $\pm S_{x}$ & 0.14 & 0.41 & 0.03 & 0.36 \\
\hline \multirow{2}{*}{4} & \multirow{2}{*}{246} & $\mathrm{X}$ & 8.83 & 73.20 & 1.38 & 12.33 \\
\hline & & $\pm \mathrm{s}_{\mathrm{x}}$ & 0.16 & 0.36 & 0.03 & 0.33 \\
\hline \multirow{2}{*}{5} & \multirow{2}{*}{364} & $\mathrm{X}$ & 9.43 & 73.65 & 1.29 & 12.06 \\
\hline & & $\pm S_{x}$ & 0.12 & 0.23 & 0.02 & 0.25 \\
\hline \multirow{2}{*}{6} & \multirow{2}{*}{458} & $\mathrm{X}$ & 9.61 & 75.23 & 1.26 & 11.87 \\
\hline & & $\pm s_{x}$ & 0.12 & 0.28 & 0.02 & 0.20 \\
\hline \multirow{2}{*}{7} & \multirow{2}{*}{331} & $\mathrm{X}$ & 8.58 & 72.48 & 1.34 & 11.19 \\
\hline & & $\pm S_{x}$ & 0.20 & 0.31 & 0.03 & 0.30 \\
\hline \multirow{2}{*}{8} & \multirow{2}{*}{90} & $\mathrm{X}$ & 8.05 & 72.33 & 1.69 & 13.74 \\
\hline & & $\pm s_{x}$ & 0.19 & 0.85 & 0.06 & 0.55 \\
\hline \multirow{2}{*}{9} & \multirow{2}{*}{49} & $\mathrm{X}$ & 7.85 & 71.02 & 1.32 & 10.66 \\
\hline & & $\pm s_{x}$ & 0.27 & 1.52 & 0.06 & 0.55 \\
\hline
\end{tabular}


depending on the aging, showing ranging averegesbetween $32.71 \%$ and $39.04 \%$.

The bulls age influences the admited doses number, wich at two years old is 257 and reaches 461 at seven years, after that it drops to 401 doses at eight years old and 252 doses at nine years.

The cryobiology rebut index is influenced by the bulls age, from the younger bulls the inappropiate batches number is higher, that fact making the stored doses number from these bulls to be smaller than adult bulls. Thereby, the bulls with ages between 2-4 years are presenting values ranging between 10.47-14.87, comparing with bulls with ages between wich 5-7 years wich are presenting values between 7.36-12.95.

At the statistic exam of deferences between avereges at analized sperm parameters according to age $(T a b .3)$ it is found that there are diferences between them, so:

- at two years old the ejaculate volume, the obtained and processed doses number presents values below bulls average, while at mobility, concentration, mobility $_{2}$, mobility $_{3}$ the values are slightly above average;

- at three years old, they were obtained values slightly over the groups average at mobility and concentration, while at the ejaculate volume, the obtained doses number, at mobility ${ }_{2}$ at mobility $_{3^{\prime}}$ as well as the admited doses number they were obtained values below bulls media;

- at the age of four years, the values for the majority of the followed parameters are below the bulls average, excepting the volume and concentration in sperms wich regestered easy values above the average;

- at five and six years old, the values for the majority of the followed parameters are above bulls average, excepting the mobility and concentration of sperms wich regestered values slightly under the average;

- at seven years old the ejaculate volume, mobility, concentrantion, mobility ${ }_{2}$, mobility presents values below the bulls average, while the number of obtained doses and the number of admited doses the values are above bulls average;

- at eight years old they were obtained values below the groups average at ejaculates volume, mobility, mobility ${ }_{2}$, mobility ${ }_{3}$ şi and for the admited doses number, while at concentration and obtained doses number they were obtained values above bulls average;

- at nine years old all the followed parameters on the raw and processed semen material are presenting values below bulls average.

Researches in this direction were made also in India by Mukesh Bhakat et al. (2011) after 5,483

Tab. 2. The influence of bulls age over the processed sperm production.

\begin{tabular}{|c|c|c|c|c|c|c|}
\hline $\begin{array}{c}\text { Age of } \\
\text { bulls } \\
\text { (years) }\end{array}$ & $\begin{array}{c}\text { Ejaculated } \\
\text { no }\end{array}$ & Statistics & $\begin{array}{l}\text { Obtained } \\
\text { doses }\end{array}$ & $\begin{array}{c}\text { Mobility } \\
2 \\
(\%) \\
\end{array}$ & $\begin{array}{c}\text { Mobility } \\
3 \\
(\%) \\
\end{array}$ & $\begin{array}{c}\text { Admitted } \\
\text { doses }\end{array}$ \\
\hline \multirow[b]{2}{*}{2} & \multirow[b]{2}{*}{168} & $\bar{X}$ & 297.14 & 37.72 & 37.72 & 257.67 \\
\hline & & $\pm s_{x}$ & 13.89 & 0.55 & 0.55 & 14.76 \\
\hline \multirow{2}{*}{3} & \multirow[b]{2}{*}{240} & $\mathrm{X}$ & 419.55 & 35.86 & 35.87 & 357.15 \\
\hline & & $\pm S_{x}$ & 12.23 & 0.46 & 0.46 & 14.26 \\
\hline \multirow[b]{2}{*}{4} & \multirow[b]{2}{*}{246} & $\mathrm{X}$ & 449.22 & 36.20 & 36.28 & 402.17 \\
\hline & & $\pm S_{x}$ & 11.92 & 0.40 & 0.41 & 14.32 \\
\hline \multirow{2}{*}{5} & \multirow{2}{*}{364} & $\mathrm{X}$ & 469.30 & 37.91 & 37.99 & 427.86 \\
\hline & & $\pm S_{x}$ & 9.91 & 0.26 & 0.26 & 11.29 \\
\hline \multirow{2}{*}{6} & \multirow{2}{*}{458} & $\mathrm{X}$ & 477.62 & 39.02 & 39.04 & 442.45 \\
\hline & & $\pm S_{x}$ & 11.45 & 0.22 & 0.22 & 12.05 \\
\hline \multirow{2}{*}{7} & \multirow{2}{*}{331} & $X$ & 529.64 & 36.30 & 36.31 & 461.04 \\
\hline & & $\pm S_{x}$ & 18.60 & 0.35 & 0.35 & 19.70 \\
\hline \multirow{2}{*}{8} & \multirow{2}{*}{90} & $X$ & 504.32 & 34.06 & 34.04 & 401.78 \\
\hline & & $\pm S_{x}$ & 20.67 & 0.92 & 0.93 & 27.58 \\
\hline \multirow{2}{*}{9} & \multirow{2}{*}{49} & $\mathrm{X}$ & 378.92 & 32.71 & 32.71 & 252.40 \\
\hline & & $\pm S_{x}$ & 18.97 & 1.16 & 1.16 & 30.15 \\
\hline
\end{tabular}


Tab. 3. The statistical importance of the differences between averages regarding semen material qualities.

\begin{tabular}{|c|c|c|c|c|c|c|c|c|c|}
\hline \multirow{2}{*}{ Specification } & \multirow{2}{*}{ M } & \multicolumn{8}{|c|}{ Age of bulls } \\
\hline & & 2 & 3 & 4 & 5 & 6 & 7 & 8 & 9 \\
\hline \multirow{2}{*}{ Volume } & $\mathrm{d}$ & -2.629 & -0.546 & 0.127 & 0.729 & 0.911 & -0.116 & -0.651 & -0.854 \\
\hline & $\mathrm{t}$ & $\mathrm{xxx}$ & ns & ns & $\mathrm{xxx}$ & $\mathrm{xxx}$ & ns & ns & ns \\
\hline \multirow{2}{*}{ Mobility } & $\mathrm{d}$ & 2.017 & 2.165 & -0.997 & -0.543 & 1.038 & -1.717 & -1.860 & -3.173 \\
\hline & $\mathrm{t}$ & $\mathrm{xx}$ & $\mathrm{xxx}$ & ns & ns & $\mathrm{x}$ & $\mathrm{xxx}$ & $\mathrm{xx}$ & $\mathrm{xx}$ \\
\hline \multirow{2}{*}{ Concentration } & $\mathrm{d}$ & 0.265 & 0.107 & 0.006 & -0.090 & -0.114 & -0.036 & 0.314 & -0.053 \\
\hline & $\mathrm{t}$ & $\mathrm{xxx}$ & $\mathrm{x}$ & ns & $\mathrm{x}$ & $\mathrm{xxx}$ & ns & $\mathrm{xxx}$ & ns \\
\hline \multirow{2}{*}{$\begin{array}{c}\text { Obtained } \\
\text { doses }\end{array}$} & $\mathrm{d}$ & -160.27 & -37.86 & -8.19 & 11.87 & 20.20 & 72.22 & 46.90 & -78.49 \\
\hline & $\mathrm{t}$ & $\mathrm{xxx}$ & ns & ns & ns & ns & $\mathrm{xx}$ & ns & ns \\
\hline \multirow{2}{*}{ Mobility 2} & $\mathrm{~d}$ & 0.617 & -1.239 & -0.901 & 0.800 & 1.915 & -0.806 & -3.048 & -4.395 \\
\hline & $\mathrm{t}$ & ns & ns & ns & ns & $\mathrm{xxx}$ & ns & $\mathrm{xxx}$ & $\mathrm{xxx}$ \\
\hline \multirow{2}{*}{ Mobility 3} & $\mathrm{~d}$ & 0.582 & -1.270 & -0.857 & 0.849 & 1.902 & -0.825 & -3.094 & -4.431 \\
\hline & $\mathrm{t}$ & ns & ns & ns & ns & $\mathrm{xxx}$ & ns & $\mathrm{xxx}$ & $\mathrm{xxx}$ \\
\hline \multirow{2}{*}{$\begin{array}{c}\text { Admitted } \\
\text { doses }\end{array}$} & $\mathrm{d}$ & -147.02 & -47.55 & -2.52 & 23.16 & 37.75 & 56.33 & -2.92 & -152.30 \\
\hline & $\mathrm{t}$ & $\mathrm{xxx}$ & ns & ns & ns & ns & $\mathrm{xx}$ & ns & $\mathrm{xx}$ \\
\hline
\end{tabular}

ejaculates were analyzed it has been found that all semen traits were significantly affected by age, except sperm concentration.

\section{CONCLUSION}

The researches confirm that the age of the bulls can influence in a significantly way the qualities of the raw and processed semen material. The results are showing, that depending on the age, the volume of the ejaculate grows, raw sperm mobility and concentration is highier at young age and regarding the obtained and admited doses number, they grow along with the age.

The harvest number at these bulls depended very much of custom requirements on bulls and the intensity of sales. Therefore also the bulls individuality (genetic base) has a strong influence upon the obtained and admited doses following the processing.

\section{REFERENCES}

1. Miclea V (2003). Însămânțarea artificială la animalele de fermă, Ed. Argonaut, Cluj-Napoca.

2. Mukesh Bhakat, TK Mohanty, VS Raina, AK Gupta, HM Khan, RK Mahapatra, M Sarkar (2011). Effect of age and season on semen quality parameters in Sahiwal bulls. \# Springer Science+Business Media B.V.

3. Acatincai S (2004). Productiile bovinelor, editia a II-a, Ed. Eurobit, Timisoara.

4. www.anarz.eu 